Int. J. Dev. Biol. 52: 979-984 (2008)

doi: $10.1387 / \mathrm{ijdb} .082710 \mathrm{~ms}$

\title{
Characterization of fibroblast-like cells from the rat olfactory bulb
}

\author{
MASOUD SOLEIMANI ${ }^{\#, *, 1}$, SAMAD NADRI ${ }^{\#, *, 2,3}$, MOHAMMAD SALEHI $^{2,4}$, ALIGHOLI SOBHANI ${ }^{4}$ \\ and ATHENA HAJARIZADEH ${ }^{5}$ \\ ${ }^{1}$ Hematology Department, Faculty of Medical Science, Tarbiat Modares University, ${ }^{2}$ Stem Cells and Tissue Engineering Department, \\ Stem Cell Technology Institute, ${ }^{3}$ Biomedical Engineering and Medical Physics Department, Faculty of Medicine, Shahid Beheshti \\ University of Medical Science, ${ }^{4}$ Anatomy Department, Faculty of Medicine, Tehran University of Medical Science and \\ ${ }^{5}$ Molecular Biology Department, Stem Cell Technology Institute, Tehran, Iran
}

\begin{abstract}
The isolation and characterization of stem cells from an alternative tissue is a subject of intensive investigation. In the present study, we have focused on the characterization of fibroblastic cells in olfactory bulb tissue of the rat. To this end, 4-6 week old rats were killed and their olfactory bulb tissue was dissected out. Olfactory bulb derived fibroblast-like cells were recovered by adhesion to cell culture plastic. The plastic adherent cultivated cells were induced to differentiate along osteoblastic, adipogenic and chondrogenic lineages. Furthermore, the expression of some surface antigens was investigated. We obtained purified cells with spindle shaped morphology in primary culture, which differentiated into mesenchymal lineages. These cells expressed CD29 and CD90 (Thy1.1) surface antigens, but not CD31, CD34 and CD45. Our results indicate that fibroblast-like cells from the olfactory bulb are mesenchymal stem cells in nature. Taken together, our data suggest that olfactory bulb tissue may constitute a new source of mesenchymal stem cells and could be used for the treatment of injury.
\end{abstract}

KEY WORDS: fibroblast-like cell, mesenchymal stem cell, surface antigen, differentiation potential

\section{Introduction}

Stem cells are a population of cells with the ability to selfrenew and to differentiate into one or more specialized cell types (Mauney etal., 2005; Odorico etal., 2001; Weissman etal., 2000). Stem cells have been considered as potential treatments for incapacitating diseases of various etiologies including diabetes, Parkinson's disease and spinal cord injury. Thus, a significant goal is to identify the variety of stem cell types displaying characteristics valuable for curing selected disorders. Many groups of stem cells including embryonic, fetal and adult stem cells have been defined to date.

Olfactory ensheathing cells (OECs) are specialized glial cells that surround the olfactory sensory axons in the nose. They have properties of Schwann cells in promoting and assisting in growth of axons (Doucette et al., 1995). They are unique among the glia in residing both inside and outside the central nervous system, in the olfactory bulb and olfactory nerve, respectively (Gudino-
Cabrera et al., 2000). These properties have led to an increasing use of olfactory unsheathing cells in preclinical models of transplantation for tissue repair (Barnett et al., 2004;Franklin et al., 1996; Raisman et al., 2001; Ramon-Cueto et al., 1994). Promising evidences have been reported with the use of OECs in a number of animal models for human diseases including ablated corticospinal tract (Li et al., 1997), fasciculus gracilis (Imaizumi et al., 2000) and treatment of injured neurons and functional recovery in the spinal cord (Ramon-Cueto et al., 1998).

Recently, researchers reported that olfactory mucosa and bulbar cell cultures of rat are contaminated with Schwann cells (SCs) and fibroblast-like cells(Rizek et al., 2006). Rizek et al. (2006) isolated and characterized SCs. However, the identity of fibroblast-like cells and their differentiation and their surface

Abbreviations used in this paper: CFU-F, colony forming unit - fibroblast; MSC, mesenchymal stem cell; OEC, olfactory ensheathing cell; SC, Schwann cell.

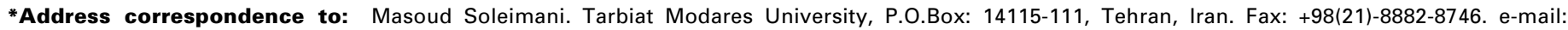

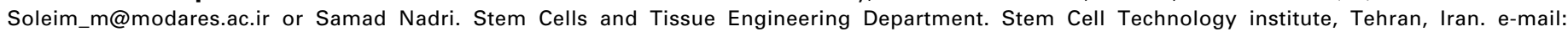
s.nadri@stemcellstech.com Web: http://www.stemcellstech.com. Tel: +98-21-8886-1065.
}

\#Note: Both authors contributed equally to this work

Published online: 14 August 2008 
antigens are unknown.

In this present study, fibroblast-like cells were isolated from culture of rat olfactory ensheathing cells and then it was demonstrated that these cells were mesenchymal stromal cells in nature.

\section{Results}

\section{Cell culture}

The cell suspension of olfactory bulb tissue was harvested from rats $(n=10)$ and plated into plastic cell culture plate in DMEM/ F12 containing 10\% fetal bovine serum (FBS; Sigma), 2mm Lglutamine (Gibco, USA) and antibiotics according to a protocol from Nash et al. (Nash et al., 2001). After 8 hours, non-lifted cells (the supernatant cells) were removed and many cells with spindle shaped morphology were seen in plastic culture plate. These cells were cultured for one week until confluence was achieved. Cell population appeared to be more homogeneous of the spindleshaped cells (e. 1A). To ensure that fibroblast-like cells were not contaminated with astrocytes and ensheathing cells, we examined expression of GFAP and P75 genes by immunocytochemistry technique. Immunocytochemistry analysis showed that GFAP and P75 markers were not expressed in isolated cells (data not shown).

To make sure that the cells did not contain cells with abnormal proliferate characteristics; we first cultured it without serum. In this condition, cells showed senescence signs and died in few days (data not shown). We then tested tumorigenic potentialities in immunodeficient mice. After four weeks of injection of cells $\left(5 \times 10^{5}\right.$ cells) into the flank area of SCID mice $(n=3)$, No sign of
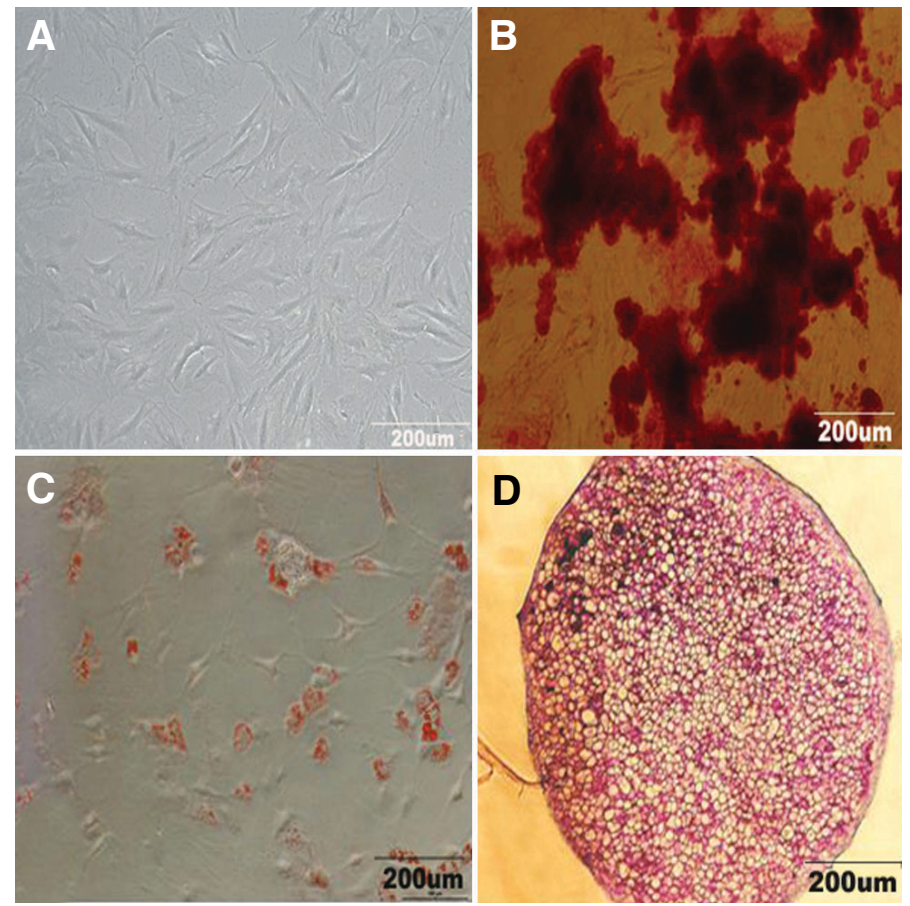

Fig. 1. Morphological characteristics and in vitro differentiation of olfactory bulb fibroblast-like cells. (A) Fibroblast-like cells have differentiated into (B) mineralizing cells stained with alizarin red, $(\mathbf{C})$ adipocytes stained with Oil red, or (D) chondrocytic lineage cells stained with Toluidine blue. (Magnification, x20).

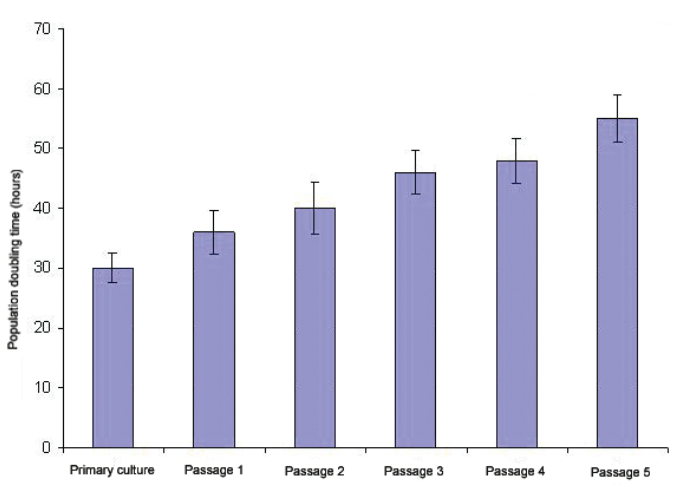

Fig. 2. Population doubling time of olfactory bulb fibroblast-like cells. The mean population doubling time of cells increased during the experimental periods of primary culture to passage 5 .

formation of tumor was observed (data not shown). The GL26 glioma cells $\left(5 \times 10^{5}\right.$ cells) were also injected into SCID mice $(n=3)$ as controls. All GL26 glioma injected animals developed tumor within 2 weeks. In summary, these data showed that our cell population was free of transformed or tumorigenic cells.

The results related to the population doubling time in different passages of the cells are shown in Fig. 2. The mean population doubling time of cells increased during the experimental periods of primary culture to passage 5 .

\section{Colony forming unit - fibroblast (CFU-F) assay}

CFU-F assay provides a convenient means of assessing the proliferation and clonogenic capacity of the cells (first passage) expanded in culture. The results showed that $76 \pm 3.4$ (Mean \pm SD) colonies were formed from fibroblast-like cells of olfactory bulb.

\section{Differentiation assay}

To induce osteocyte differentiation, confluent cells were further cultured in osteoinductive medium for three weeks. In some areas of the culture dish, nodule-like structures were observed. Following alizarin red staining, red mineralizing areas of cultures appeared (Fig. 1B). To further demonstrate differentiation of cells, we analyzed the expression of osteoblast-specific markers before (day 0) and after treatment with the inductive medium (day 21) using RT-PCR (Fig. 3A). More than $95 \%$ of the cells exhibited osteogenic differentiation. Osteonectin (OC), osteopontin (OP), integrin bone sialoprotein (IBSP) and alkaline phosphatase (ALP) were expressed in the osteoinductive cultures, while they were never expressed in the control medium.

To induce adipocyte differentiation, the cells were cultured in adipoinductive medium for 3 weeks. In adipogenic cultures, small lipid droplets appeared within the cytoplasm of the cells first on day 14 . The lipid droplets turned red when stained by the Oil-red O staining method (Fig. 1C). More than $60 \%$ of the cells exhibited adipogenic differentiation. RT-PCR analysis was also indicative of the expression of lipoprotein lipase (LPL) and peroxisome proliferator-activated receptor-Â (PPAR-Â) in the adipoinductive cultures (Fig. 3B).

Likewise, to induce chondrocyte differentiation the cell population was cultured in micro plates and in chondroinductive medium for three weeks. The accumulation of cartilaginous 
proteoglycans was demonstrated by the Toluidine blue staining method (Fig. 1D), and its marker molecules were examined by RT-PCR analysis (Fig. 3C). Notably, more than 95\% of the cells exhibited chondrogenic differentiation. Aggrecan was expressed in the cells treated with chondroinductive medium for 21 days.

\section{Epitope analysis}

The cells were analyzed for the expression of a panel of antigens, as shown in Fig. 4. Results showed that the cells were negative for the CD31, CD45, CD11b and CD34, and were stained by monoclonal antibody directed against Thy1.1 (CD90) and CD29.

\section{Discussion}

Olfactory ensheathing cells (OECs) are believed to be responsible for the ability of olfactory axons to innervate this area of the adult mammalian CNS over a lifetime(Wang et al., 2007; Wang et al., 2006). The ability of transplanted ensheathing cells (ECs) to promote axonal regrowth in areas of the CNS has been reported by researchers. Olfactory bulb cells have been found to contain different cell types including fibroblasts, astrocytes and ECs (Nash et al., 2001). In spite of ECs, there has been minimal information on the characterization of fibroblast-like cells of olfactory bulb. In the present study, we have examined the isolation and characterization of fibroblast-like cells from olfactory bulb of adult rats.

A number of regeneration studies have transplanted both purified and non purified OECs. Transplanted OECs were found to support regenerating dorsal root axons into a rhizotomized spinal cord (Ramon-Cueto et al., 1994) and facilitate axonal elongation in adult rat brain after fimbria-fornix transection (Smale et al., 1996). Nonpurified OECs promote axonal elongation into and
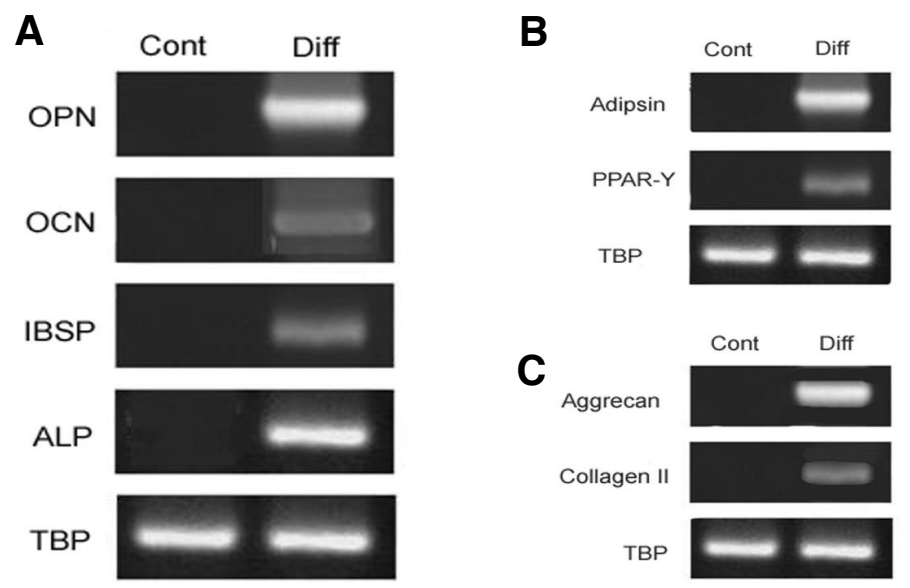

Fig. 3. Differentiation-specific gene expression. (A) Expression of osteoblast markers including osteopontin (OPN), osteonectin (OCN), integrin bone sialoprotein (IBSP) and alkaline phosphatase (ALP) was analyzed in control (day 0) and differentiation culture (day 21). (B) Expression of adipocytic markers including lipoprotein lipase (LPL) and peroxisome proliferator-activated receptor- $\gamma$ (PPAR- $\gamma$ ) was analyzed in control (day 0) and differentiation culture (day 21). (C) Expression of chondrocyte markers such as aggrecan and collagen type II was evaluated in control (day 0) and differentiation culture(day 21).
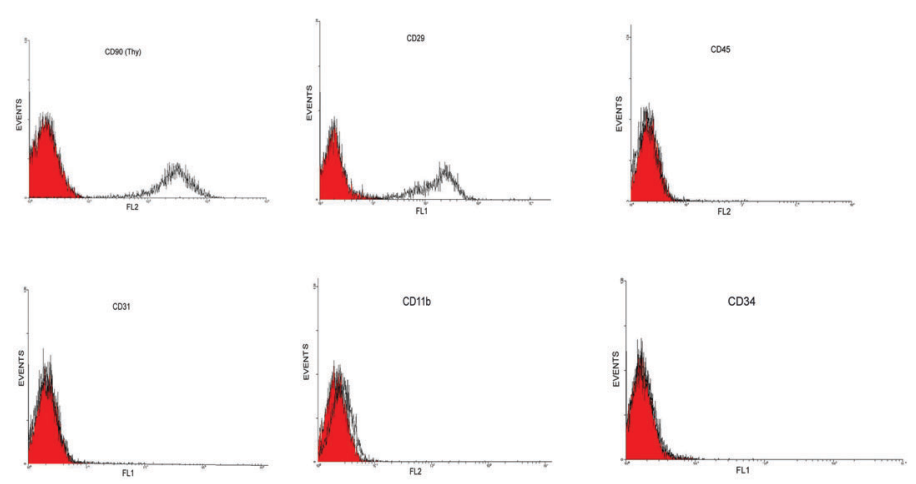

Fig. 4. Flow cytometry analysis of olfactory bulb fibroblast-like cells. Fibroblast-like cells are analyzed by fluorescence-activated cell sorting and Cell Quest software for the expression of certain markers.

beyond corticospinal tract lesions (Li et al., 1997;Li et al., 1998) corresponding to the migration path of the transplanted olfactory cells. Partial recovery of corticospinal tract function was also reported (Li et al., 1997). In the present study, olfactory bulb fibroblast-like cells (OBFLCs) can be enriched only using adherence to culture plastic and by a rather simple approach. We have isolated fibroblast-like cells from olfactory bulb with some changes in a Nash et al. protocol(Nash et al., 2001). In the present study, the culture medium was changed after 8 hours of primary culture of olfactory bulb while Nash et al. changed it after 18 hours. Using the method described in this study, diminishing the time of medium change can prevent adherence of EC and astrocytes to the culture dish. We have obtained purified populations of fibroblast-like cells from rat olfactory bulb. Our results showed that P75 and GFAP were not expressed in isolated cells (data not shown). Previous studies showed that $P 75$ was expressed in EC (RamonCueto et al., 1992), while GFAP was expressed in both EC (Ramon-Cueto et al., 1994) and astrocytes (Bignami et al., 1973).

Certain properties of the isolated cells (fibroblast-like cells) by this approach convinced us that they were mesenchymal stem cells (MSCs). These cells simply differentiated into mesenchymal lineages in appropriate media. To identify rat MSCs, many researchers propose that these cells should express a high level of CD29 (receptor for ECM) and CD90 (Thy) (found on the surfaces of thymocytes, neurons, epidermal cells and fibroblasts) (Mirsky etal., 1975;Reif etal., 1964;Scheid etal., 1972;Stern et al., 1973), and lack expression of hematopoietic epitopes (CD45, CD34, CD11b, CD31) (Marcus et al., 2007). Flow cytometry analysis of OBFLCs is in agreement with these previous data. Finally, clonogenic potential, spindle shaped morphology, and differentiation into mesenchymal lineages and surface antigens detected in isolated cells convinced us that OBFLCs from olfactory bulb were MSCs.

MSCs have been considered as an appropriate source for cell and gene therapy tools for treatment in a number of congenital and degenerative diseases (Baksh et al., 2004). Promising evidences have been reported with the use of cells in a number of animal models for human diseases, including models for osteogenesis imperfecta (Horwitz et al., 2002), spinal cord injury (Sasaki et al., 2001)stroke (Chen et al., 2003), and Parkinsonism (Schwarz et al., 1999). 
The results of our study indicated that we have isolated fibroblastic cells with MSCs characteristic from olfactory bulb of rat. Therefore, transplantation of fibroblast cells of olfactory bulb could be valuable for treatment of human diseases. Previous studies have transplanted both purified and non purified ECs in spinal cord injury (Nash et al., 2001). In conclusion, the results presented in this study suggest that fibroblast-like cells from olfactory bulb tissue with clonogenic potential, capable of differentiating into osteogenic, adipogenic and chondrogenic lineages, spindle shaped morphology and surface antigens (CD29+,

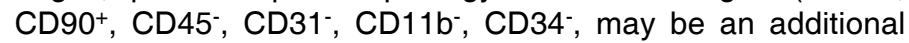
source of unique, mesenchymal stem cells with a multi-germ line potential.

\section{Materials and Methods}

\section{Cell cultures}

Ten adult rats (200-250g, Razi Institute, Karaj, Iran), 6-8 weeks old, were used in this study. Adult rats were anesthetized with $10 \%$ chloral hydrate and killed by decapitation. A skin incision was made in the scalp extending from the tip of the nose to the occipital bone of the skull, the nasal and frontal bones were removed. The olfactory bulbs were dissected free of all obvious signs of meningeal tissue. The olfactory bulbs were detached and placed in $10 \mathrm{ml}$ of chilled calcium and magnesium free hanks balanced salt solution (HBSS, biofluids, Rockville, MD). Then, the tissues were incubated within a solution of $0.25 \%$ collagenase type IA and dispasell $(2.4 \mathrm{U} / \mathrm{ml}$ in Puck s solution; Roche Diagnostics, Mannheim, Germany) in DMEM/F12 (Invitrogen, Burlington, Ontario, Canada) for 30 minutes at $37^{\circ} \mathrm{C}$ in $5 \% \mathrm{CO}_{2}$. The tissue was then mechanically dissociated, after which the dispase and collagenase activity was inactivated using HBSS. The cell suspensions were then centrifuged at $300 \mathrm{~g}$ for 5 minutes and plated into plastic cell culture plates in DMEM/F12 (Invitrogen, Burlington, Ontario, Canada) containing 10\% fetal bovine serum (FBS; Sigma), 2mm L-glutamine (Gibco, USA), $100 \mathrm{u} / \mathrm{ml}$ penicillin (Sigma) and $100 \mathrm{u} / \mathrm{ml}$ streptomycin (Sigma). Cultures were kept at $37^{\circ} \mathrm{C}$ in a humidified atmosphere containing $95 \%$ air and $5 \% \mathrm{CO}_{2}$ for 8 hours. The supernatants from the culture were removed and when primary cultures became nearly confluent, the culture was treated with $0.5 \mathrm{ml}$ of $0.025 \%$ trypsin containing $0.02 \%$ EDTA for 2 minutes at room temperature. These cells were examined for further experiments.

\section{Immunocytochemistry}

The cells were cultured on sterile glass cover slips and fixed by incubation in $1 \%$ Paraformaldehyde/PBS for 3-5 min, permeabilized with $0.5 \%$ Triton X-100 in PBS for $15 \mathrm{~min}$, and post fixed for 10 additional minutes in $4 \%$ Paraformaldehyde in PBS. The intracellular staining patterns and distribution of GFAP and P75 proteins were analyzed by immunostaining with a GFAP (Sigma) monoclonal antibody (mAb) (Chemicon) and mouse anti-rat P75 (Abcam), respectively. The fluorescent isothiocyanate (FITC)-conjugated anti-mouse IgG was used as the secondary antibody (Sigma).

\section{Tumorigenic assay}

Immunodeficient mice (SCID mice; $n=3$ ), 4 weeks old, were subcutaneously injected with $5 \times 10^{5}$ cells in $50 \mu$ of DMEM containing FBS, Lglutamine and antibiotic. Three SCID mice were inoculated with GL26 glioma cells as controls. Injected mice were monitored for tumor formation for 60 days.

\section{Proliferation potential in varying passages}

The cells were cultured in a $25-\mathrm{cm}^{2}$ plastic flask in complete medium. Three days after culture initiation, i.e. when confluency had been achieved, the cells were subcultured and divided into two $25-\mathrm{cm}^{2}$ flasks. They were subsequently placed in an incubator until confluency, at which time another passage was initiated. Subculture of the cells was performed up to passage 5 , and the population doubling time was determined at varying passages up to passage 5 . The mean population doubling time was calculated according to the equation TD $=t_{p} \log _{2} /\left(\log _{N t}-\log _{N 0}\right)$, where NO is the number of cultivated cells, $N_{t}$ is the number of harvested cells and $t$ is the time of culture (in h). The SPSS software package (Version 12.0; SPSS Inc., Chicago, IL, USA) was used for the statistical tests. Data are presented as mean $\pm S D$.

\section{Colony forming unit-fibroblast (CFU-F) assay}

The clonogenic potential of the isolated cells (first passage) was tested for the colony formation potentials. For this assay, 100 cells were plated on a $60 \mathrm{~mm}^{2}$ cell culture dish and incubated for 7 days. Subsequently, the plates were stained with $3 \%$ crystal violet in methanol for 10 minutes. All visible colonies were counted.

\section{Differentiation assays}

The potential of the isolated cells to differentiate into osteogenic and adipogenic lineages was examined for osteogenesis. The cultured cells were incubated in osteogenic conditioned medium (Eslaminejad et al., 2006;Nadri et al., 2007). Briefly, DMEM was supplemented with $10 \mathrm{mM} \beta$ glycerol phosphate (Sigma), $50 \mu \mathrm{g} / \mathrm{ml}$ ascorbate-2-phosphate (Sigma) and $10^{-7} \mathrm{M}$ dexamethasone (Sigma) (Nadri et al., 2007). The culture medium was changed two times per week for up to three weeks. The cells were fixed with methanol for 10 minutes at room temperature and stained with alizarin red with $\mathrm{pH}=4$ for 5 minutes at room temperature. Treated cells were subjected to RNA extraction and RT-PCR analysis.

For adipogenesis, the cultured cells were incubated in adipogenic medium DMEM supplemented with $50 \mu \mathrm{g} / \mathrm{ml}$ Indomethacin (Sigma), 10${ }^{7} \mathrm{M}$ dexamethasone (Sigma), and $50 \mu \mathrm{g} / \mathrm{ml}$ ascorbate-2-phosphate (Sigma) (Eslaminejad et al., 2006;Nadri et al., 2007). The culture medium was changed two times per week for up to three weeks. The cells were then fixed in methanol for 45 minutes and stained with Oil Red (Sigma). The cells were also used for RNA extraction and RT-PCR analysis of adipogenic gene expression.

For chondrogenesis, a micro mass culture technique was used. Approximately 200000 cells were pelleted by centrifugation at $300 \mathrm{~g}$ for four minutes, followed by incubation at $37^{\circ} \mathrm{C}$ in $5 \% \mathrm{CO}_{2}$ in a $0.5 \mathrm{ml}$ chondrogenic medium, composed of DMEM supplemented with $10 \mathrm{ng} / \mathrm{ml}$ transforming growth factor $\beta_{3}$ (TGF- $\beta_{3}$ ) (Sigma), $500 \mathrm{~g} / \mathrm{ml}$ bone morphogenetic protein-6 (BMP-6), $10^{-7} \mathrm{M}$ dexamethasone(sigma), and $50 \mu \mathrm{g} / \mathrm{ml}$ ascorbate -2- phosphate(sigma), $50 \mathrm{~g} / \mathrm{ml}$ insuline-transfferrine-selenium (ITS) (Gibco).The cultures were maintained for 3 weeks with medium change at 3 day intervals. At the end of this period, for Toluidine blue staining, some pellets were fixed with $10 \%$ formalin, embedded in paraffin, sectioned at $0.3 \mu \mathrm{m}$ and stained for histology(Nadri et al., 2008). The remaining pellets were used for RT-PCR analysis of chondrocytic marker gene expression.

\section{RNA extraction and RT-PCR analysis of gene expression}

Total RNA was isolated from cells by using the Nucleospin RNAll kit (Macherey-Nagel, Germany). Prior to reverse transcription (RT), RNA samples were digested with DNasel (EN0521; Fermentas) to remove contaminating genomic DNA. DNase I was dissolved in 10X reaction buffer with $\mathrm{MgCl}_{2}$, and $1 \mathrm{u} / \mu \mathrm{l}$ of DNase I was added per $1 \mu \mathrm{g}$ of RNA and incubated for $30 \mathrm{~min}$ at $37^{\circ} \mathrm{C}$. DNasel activity was arrested following addition of $1 \mu \mathrm{l}$ of $25 \mathrm{mM}$ EDTA and incubated at $65^{\circ} \mathrm{C}$ for 10 minutes. Standard RT was performed using the RevertAid ${ }^{\mathrm{TM}} \mathrm{H}$ Minus First Strand cDNA Synthesis Kit (Fermentas) and $2 \mu \mathrm{g}$ total RNA, $0.5 \mu \mathrm{g}$ oligo ( $\mathrm{dt}_{18}$ ) per reaction, according to the manufacturer's instructions. Reaction mixtures for PCR included $2.5 \mu \mathrm{l} \mathrm{cDNA}, 1 \times$ PCR buffer (AMS ${ }^{\mathrm{TM}}$,Sinagen, Iran), $200 \mu \mathrm{M}$ dNTPs, $0.5 \mu \mathrm{M}$ of each of Forward and Reverse primers and $1 U$ Taq DNA polymerase(Fermentas, MD, USA). The primers are listed in Table 1. Polymerase chain reactions were performed at $94^{\circ} \mathrm{C}$ for $1 \mathrm{~min}$, $25-30$ cycles $94^{\circ} \mathrm{C}$ for 30 s, $55-63^{\circ} \mathrm{C}$ for 30 s, and $72^{\circ} \mathrm{C}$ for 30 s and $72^{\circ} \mathrm{C}$ 
TABLE 1

\section{SPECIFIC PRIMERS USED FOR PCR AMPLIFICATION}

\begin{tabular}{|c|c|c|}
\hline Genes & Primer sequences & $\begin{array}{l}\text { Accession } \\
\text { Number }\end{array}$ \\
\hline Osteonectin(OCN) & $\begin{array}{l}\text { F: } \text { AGGACCCTC TCTCTGCTCAC } \\
\text { R: }\end{array}$ & NM_013414.1 \\
\hline Osteopontin(OPN) & $\begin{array}{l}\text { F: AGAGGAGAAGGCGCATTACA } \\
\text { R: GCAACTGGGATGACCTTGAT }\end{array}$ & NM_012881.2 \\
\hline $\begin{array}{l}\text { Alkalin } \\
\text { phosphatase(ALPs) }\end{array}$ & $\begin{array}{l}\text { F: TTAAGGGCCAGCTACACCAC } \\
\text { R: GATAGGCGATGTCCTTGCAG }\end{array}$ & NM_013059.1 \\
\hline $\begin{array}{l}\text { Integrin binding } \\
\text { Sialoprotein (IBSP) }\end{array}$ & $\begin{array}{l}\text { F: CGCCTACTTTTATCCTCCTCTG } \\
\text { R: CTGACCCTCGTAGCCTTCATAG }\end{array}$ & NM_012587.2 \\
\hline Adipsin & $\begin{array}{l}\text { F: CAGTGCAAGTGAATGGCACGCAACG } \\
\text { R: TCAATCCACGGCACGTAGGTTGCC }\end{array}$ & NM_001077642.1 \\
\hline $\begin{array}{l}\text { Peroxisome proliferator- } \\
\text { activated receptor- } \gamma \\
\text { (PPAR- } \gamma \text { ) }\end{array}$ & $\begin{array}{l}\text { F: CCTGTTGACCCAGAGCATG } \\
\text { R: ACCTGATGGCATTGTGAGAC }\end{array}$ & NM_013124 \\
\hline Aggrecan & $\begin{array}{l}\text { F: AGGACCAGACTGTCAGATACC } \\
\text { R: GTGAACTGCTCCATTTGTGTG }\end{array}$ & NM_022190.1 \\
\hline Collagen Type II & $\begin{array}{l}\text { F: AATGGCGAGAAGGGAGAAGTC } \\
\text { R: GAATCCAGCAGGTCCAGGTG }\end{array}$ & NM_012929.1 \\
\hline $\begin{array}{l}\text { TATA box binding protein } \\
\text { (TBP) }\end{array}$ & $\begin{array}{l}\text { F: CCTTGTGTTGACCCACCACAGTTCAGTAG } \\
\text { R: ACAGGAGTCCATGGCAGACAACTATGTGG }\end{array}$ & NM_001004198.1 \\
\hline
\end{tabular}

for 10 minutes. Amplified DNA fragments were electrophoresed on $1.5 \%$ agarose gel. The gels were stained with ethidium bromide $(10 \mu \mathrm{g} / \mathrm{ml})$ and photographed on a UV transilluminator (uvidoc, UK).

\section{Flow cytometry analysis}

The cultured cells (passage 2) were detached with Trypsin/ EDTA and counted. About $2 \times 10^{5}$ cells were divided into aliquots in amber-tinted $5 \mathrm{ml}$ centrifuge tubes and $3 \%$ rat serum was added. The cells were incubated on ice for 30 minutes, resuspended in $400 \mu$ l PBS and pelleted by centrifugation for 10 minutes at $400 \mathrm{xg}$. Next, the cells were stained with fluorescent isothiocyanate (FITC)-conjugated mouse anti-rat CD31 (Abd Serotec), CD34 (CEDARLANE), CD29 (Becton Dickinson), Phycoerythrin (PE)-conjugated mouse anti-rat CD45 (Biolegend), CD90 1.1(eBioscience, San Diego, CA, USA) and CD11b (BD Biosciences) at a concentration of $2 \mu \mathrm{g} / \mathrm{ml}$ at $4^{\circ} \mathrm{C}$ for 30 minutes. The cells were also stained with FITC-or PE-labeled mouse anti-rat IgG1,2 as negative controls. The cells were pelleted, washed twice with PBS and fixed with $1 \%$ paraformaldehyde in PBS. After fixation, FACS analysis was performed on a FACS Callibur cytometry (Becton Dickinson, San Jose, CA) using cell quest software. Win MDI 2.8 software was used to create the histograms.

\section{Acknowledgment}

This study was supported by Iran Stem Cell Technology Institute.

\section{References}

BAKSH, D., SONG, L AND TUAN, R S. (2004). Adult mesenchymal stem cells: characterization, differentiation, and application in cell and gene therapy. $J$ Cell MolMed8: 301-16.

BARNETT, S.C. AND CHANG, L. (2004). Olfactory ensheathing cells and CNS repair: going solo or in need of a friend? Trends Neurosci27: 54-60.

BIGNAMI, A AND DAHL, D. (1973). Differentiation of astrocytes in the cerebellar cortex and the pyramidal tracts of the newborn rat. An immunofluorescence study with antibodies to a protein specific to astrocytes. Brain Res 49: 393-402.

CHEN, J., ZHANG, Z.G., LI, Y., WANG, L., XU, Y.X., GAUTAM, S.C., LU, M., ZHU, Z. AND CHOPP, M. (2003). Intravenous administration of human bone marrow stromal cells induces angiogenesis in the ischemic boundary zone after stroke in rats. Circ Res 92: 692-9.

DOUCETTE, R. (1995). Olfactory ensheathing cells: potential for glial cell transplantation into areas of CNS injury. Histol Histopatho/ 10: 503-7.

ESLAMINEJAD, M.B., NIKMAHZAR, A., TAGHIYAR, L., NADRI, S. AND MASSUMI,
M. (2006). Murine mesenchymal stem cells isolated by low density primary culture system. Dev Growth Differ 48: 361-70.

FRANKLIN, R.J., GILSON, J.M., FRANCESCHINI, I.A. AND BARNETT, S.C. (1996) Schwann cell-like myelination following transplantation of an olfactory bulbensheathing cell line into areas of demyelination in the adult CNS. Glia 17: 21724.

GUDINO-CABRERA, G AND NIETO-SAMPEDRO, M. (2000). Schwann-like macroglia in adult rat brain. Glia 30: 49-63.

HORWITZ, E.M., GORDON, P.L., KOO, W.K., MARX, J.C., NEEL, M.D., MCNALL, R.Y., MUUL, L. AND HOFMANN, T. (2002). Isolated allogeneic bone marrowderived mesenchymal cells engraft and stimulate growth in children with osteogenesis imperfecta: Implications for cell therapy of bone. Proc Nat/ Acad SciUS A 99: 8932-7.

IMAIZUMI, T., LANKFORD, K.L. AND KOCSIS, J.D. (2000). Transplantation of olfactory ensheathing cells or Schwann cells restores rapid and secure conduction across the transected spinal cord. Brain Res 854: 70-8.

LI, Y.FIELD, P M AND RAISMAN, G. (1997). Repair of adult rat corticospinal tract by transplants of olfactory ensheathing cells. Science $277: 2000-2$.

LI, Y.FIELD, P M AND RAISMAN, G. (1998). Regeneration of adult rat corticospinal axons induced by transplanted olfactory ensheathing cells. JNeurosci18: 1051424.

MARCUS, A.J., COYNE, T.M., RAUCH, J., WOODBURY, D. AND BLACK, I.B. (2007). Isolation, characterization, and differentiation of stem cells derived from the rat amniotic membrane. Differentiation

MAUNEY, J.R., VOLLOCH, V. AND KAPLAN, D.L. (2005). Role of adult mesenchymal stem cells in bone tissue engineering applications: current status and future prospects. Tissue Eng 11: 787-802.

MIRSKY, R AND THOMPSON, E J. (1975). Thy 1 (theta) antigen on the surface of morphologically distinct brain cell types. Cel/4: 95-101.

NADRI, S., SOlEIMANI, M., HOSSENI, R.H., MASSUMI, M., ATASHI, A. AND IZADPANAH, R. (2007). An efficient method for isolation of murine bone marrow mesenchymal stem cells. Int J Dev Bio/51: 723-9.

NADRI, S., SOLEIMANI, M., KIANI, J., ATASHI, A. AND IZADPANAH, R. (2008). Multipotent mesenchymal stem cells from adult human eye conjunctiva stromal cells. Differentiation 76: 223-31.

NASH, H.H., BORKE, R.C. AND ANDERS, J.J. (2001). New method of purification for establishing primary cultures of ensheathing cells from the adult olfactory bulb. Glia 34: 81-7.

ODORICO, J.S., KAUFMAN, D.S. AND THOMSON, J.A. (2001). Multilineage differentiation from human embryonic stem cell lines. Stem Cells 19: 193-204.

RAISMAN, G. (2001). Olfactory ensheathing cells - another miracle cure for spinal cord injury? Nat Rev Neurosci2: 369-75.

RAMON-CUETO, A. AND NIETO-SAMPEDRO, M. (1992). Glial cells from adult rat olfactory bulb: immunocytochemical properties of pure cultures of ensheathing cells. Neuroscience 47: 213-20.

RAMON-CUETO, A. AND NIETO-SAMPEDRO, M. (1994). Regeneration into the spinal cord of transected dorsal root axons is promoted by ensheathing glia transplants. Exp Neuro/127: 232-44.

RAMON-CUETO, A., PLANT, G.W., AVILA, J. AND BUNGE, M.B. (1998). Longdistance axonal regeneration in the transected adult rat spinal cord is promoted by olfactory ensheathing glia transplants. JNeurosci 18: 3803-15.

REIF, A.E. ANDALLEN, J.M. (1964). The Akr Thymic Antigen and Its Distribution in Leukemias and Nervous Tissues. J Exp Med120: 413-33.

RIZEK, P.N AND KAWAJA, M.D. (2006). Cultures of rat olfactory ensheathing cells are contaminated with Schwann cells. Neuroreport 17: 459-62.

SASAKI, M., HONMOU, O., AKIYAMA, Y., UEDE, T., HASHI, K. AND KOCSIS, J.D (2001). Transplantation of an acutely isolated bone marrow fraction repairs demyelinated adult rat spinal cord axons. Glia 35: 26-34.

SCHEID, M., BOYSE, E.A., CARSWELL, E.A. AND OLD, L.J. (1972). Serologically demonstrable alloantigens of mouse epidermal cells. J Exp Med135: 938-55.

SCHWARZ, E.J., ALEXANDER, G.M., PROCKOP, D.J. AND AZIZI, S.A. (1999) Multipotential marrow stromal cells transduced to produce L-DOPA: engraftment in a rat model of Parkinson disease. Hum Gene Ther 10: 2539-49.

SMALE, K.A., DOUCETTE, R. AND KAWAJA, M.D. (1996). Implantation of olfactory ensheathing cells in the adult rat brain following fimbria-fornix transection. Exp 
Neurol137: 225-33.

STERN, P.L. (1973). Theta alloantigen on mouse and rat fibroblasts. Nat New Biol 246: $76-8$.

WANG, B., HAN, J., GAO, Y., XIAO, Z., CHEN, B., WANG, X., ZHAO, W. AND DAI, J. (2007). The differentiation of rat adipose-derived stem cells into OEC-like cells on collagen scaffolds by co-culturing with OECs. Neurosci Lett 421: 191-6.
WANG, B., ZHAO, Y., LIN, H., CHEN, B., ZHANG, J., ZHANG, J., WANG, X., ZHAO, W. AND DAI, J. (2006). Phenotypical analysis of adult rat olfactory ensheathing cells on 3-D collagen scaffolds. Neurosci Lett 401: 65-70.

WEISSMAN, I.L. (2000). Translating stem and progenitor cell biology to the clinic: barriers and opportunities. Science 287: 1442-6.

\section{Further Related Reading, published previously in the Int. J. Dev. Biol.}

See our Special Issue Fertilization in honor of David Garbers and edited by P.M. Wassarman and V.D. Vacquier at: http://www.ijdb.ehu.es/web/contents.php?vol=52\&issue=5/6

See our Special Issue Developmental Biology in Poland edited by Tarkowski, Maleszewski and Kloc at: http://www.ijdb.ehu.es/web/contents.php?vol=52\&issue=2-3

An efficient method for isolation of murine bone marrow mesenchymal stem cells Samad Nadri, Masoud Soleimani, Reza H. HosSeni, Mohammad Massumi, Amir Atashi and Reza Izadpanah Int. J. Dev. Biol. (2007) 51: 723-729

Experimental study of early olfactory neuron differentiation and nerve formation using quail-chick chimeras

Fabrice L. Lalloué and Christiane S. Ayer-Le Lièvre

Int. J. Dev. Biol. (2005) 49: 193-200

Heparan sulfates isolated from adult neural progenitor cells can direct phenotypic maturation.

Hiram Chipperfield, Kuldip S Bedi, Simon M Cool and Victor Nurcombe Int. J. Dev. Biol. (2002) 46: 661-670

Expression of neurexin ligands, the neuroligins and the neurexophilins, in the developing and adult rodent olfactory bulb.

Heidi J Clarris, Sonja McKeown and Brian Key

Int. J. Dev. Biol. (2002) 46: 649-652

Multiple axon guidance cues establish the olfactory topographic map: how do these cues interact?

James A St John, Heidi J Clarris and Brian Key

Int. J. Dev. Biol. (2002) 46: 639-647

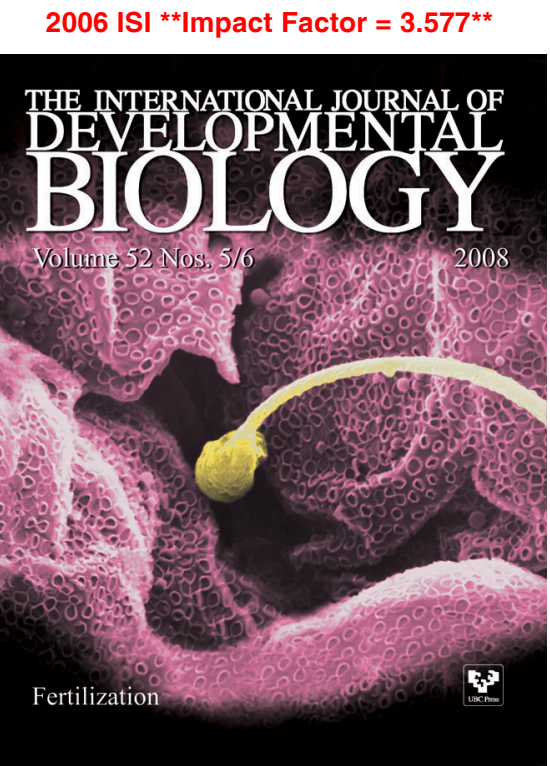

